\title{
Study of the relation between subcutaneous wound drainage after midline sternotomy and surgical site infections in obese patients
}

\author{
Vaibhav Shah, Chaitanya Hemant Raut, Prashant Mishra, Harsh Seth, Manish Jadhao, Vijay Shewale
}

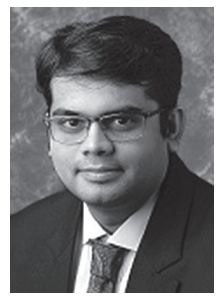

Department of Cardiovascular and Thoracic Surgery, Lokmanya Tilak Municipal Medical College and General Hospital, Mumbai, India Kardiochir Torakochir Pol 2019; 16 (4): 160-165

\begin{abstract}
Introduction: Surgical site infection (SSI) is an important morbidity postoperatively after midline sternotomy in patients undergoing cardiac surgery. Collected blood and serous fluids can get infected, which is one of the many factors responsible for surgical site infection, especially in obese patients.

Aim: To observe the association of SSI with and without prophylactic use of subcutaneous wound drainage in obese patients undergoing cardiac surgery via midline sternotomy.

Material and methods: A retrospective observational study of 152 obese patients who underwent cardiac surgery via midline sternotomy was conducted. Data were analysed after retrieving records between two groups of patients - those who received a prophylactic subcutaneous wound drain (group A) and those who did not (group B) after surgery in terms of superficial and deep surgical site infection including mediastinitis, need for second surgery, VAC dressing, hospital stay and need for readmission. Results: Retrieved data showed that 27 obese patients of the $128(21 \%)$ developed SSI after cardiac surgery via midline sternotomy. Deep sternal wound infection (DSWI) was significantly higher in patients from group B than group A. Multivariate analysis did not show a statistically significant decrease due to suction drains. Superficial infection, though higher, was not statistically significantly different between the two groups. The hospital stay was found to be longer and statistically significant in group $B$ patients than group A.

Conclusions: There was a decrease in the incidence of DSWI in obese patients receiving prophylactic subcutaneous wound drainage after cardiac surgery via midline sternotomy but the difference was not statistically significant.
\end{abstract}

Key words: surgical site infection, deep sternal wound infection, VAC.

\section{Streszczenie}

Wprowadzenie: Zakażenie miejsca operowanego (SSI) stanowi istotne powikłanie pooperacyjne sternotomii pośrodkowej u pacjentów poddawanych operacji kardiochirurgicznej. Jednym z wielu czynników odpowiedzialnych za rozwój zakażenia miejsca operowanego, zwłaszcza u pacjentów otyłych, jest zakażenie zbierającej się krwi i treści surowiczej.

Cel: Analiza zależności między występowaniem SSI a profilaktycznym stosowaniem podskórnego drenażu rany u pacjentów otyłych poddanych zabiegom kardiochirurgicznym przez sternotomię pośrodkową.

Materiał i metody: Przeprowadzono retrospektywne badanie obserwacyjne obejmujące 152 pacjentów z otyłością poddanych operacji kardiochirurgicznej z dostępu przez sternotomię pośrodkową. Przeanalizowano dane pozyskane z dokumentacji dwóch grup pacjentów - osób, u których profilaktycznie wykonano podskórny drenaż rany (grupa A), i chorych, u których nie wykonano tej procedury (grupa B). Analizie poddano następujące czynniki: powierzchowne i głębokie zakażenia miejsca operowanego, w tym zapalenie śródpiersia, konieczność przeprowadzenia kolejnej operacji, zaopatrzenie rany metodą VAC, długość pobytu w szpitalu oraz konieczność ponownej hospitalizacji.

Wyniki: Na podstawie zebranych danych wykazano, że SSI wystąpiło u 27 (21\%) spośród 128 otyłych pacjentów poddanych operacji kardiochirurgicznej przez sternotomię pośrodkową. Częstość występowania głębokiego zakażenia rany mostka była istotnie wyższa u pacjentów z grupy B w porównaniu z grupą A. Analiza wieloczynnikowa nie wykazała jednak statystycznie istotnego zmniejszenia częstości występowania tego powikłania po zastosowaniu drenów ssących. Częstość występowania powierzchownego zakażenia rany była wprawdzie wyższa, jednak różnica między dwiema badanymi grupami nie była istotna statystycznie. Stwierdzono, że okres pobytu w szpitalu pacjentów z grupy B był statystycznie istotnie dłuższy w porównaniu z pacjentami z grupy A. Wnioski: Zaobserwowano zmniejszenie częstości występowania głębokiego zakażenia rany mostka u pacjentów otyłych poddawanych profilaktycznie podskórnemu drenażowi rany po operacji kardiochirurgicznej z dostępu przez sternotomię pośrodkową, jednak różnica ta nie była istotna statystycznie.

Słowa kluczowe: zakażenie miejsca operowanego, głębokie zakażenie rany mostka, VAC.

Address for correspondence: Dr Chaitanya Hemant Raut, Department of Cardiovascular and Thoracic Surgery, Lokmanya Tilak Municipal Medical College and General Hospital, Mumbai, India, e-mail: drrautchaitanya@gmail.com Received: 2.09.2019, accepted: 12.11.2019. 


\section{Introduction}

Post-sternotomy wound infection is an uncommon but serious complication after cardiac surgery [1]. It accounts for $14-16 \%$ of nosocomial infections. Surgical site infections including superficial and deep wound infections such as mediastinitis are associated with increased morbidity, extended hospital stay, repeated surgery, prolonged antibiotic use and sometimes mortality. As a result, the costs for patients with sternal wound infections have been estimated to be 2-8 times greater than for patients with a normal postoperative course [1].

Multiple factors have been attributed to surgical site infection (SSI) after cardiac surgery via midline sternotomy incision. These include diabetes mellitus, smoking, body mass index (BMI) and obesity, chronic renal failure, peripheral vascular disease, use of bilateral internal thoracic arteries for grafting, excessive use of electrocautery and bone wax, prolonged surgery, emergency surgery, re-exploration, etc. Previous studies have suggested a risk of $7-23 \%$ of developing SSI in obese patients.

It has been postulated that the presence of hematoma, serous fluid, and dead space in surgical incision wounds act as a culture medium and thus increase the risk for developing SSI [2, 3]. Use of subcutaneous drains prevents formation of seroma and hematoma and also eliminates the dead space occurring in obese patients having thick subcutaneous fat tissue. It has been shown that application of negative pressure imparts positive effects on the healing of the wound and formation of granulation tissue, resulting in faster wound healing [4].

However, routine use of post-operative prophylactic subcutaneous wound drainage is not universally accepted, while some studies have shown that drains may not be efficacious and increase the discomfort and increased hospital stay [5].

\section{Aim}

The study aims to correlate the prophylactic use of subcutaneous wound drainage with post-sternotomy SSI in obese patients after cardiac surgery via midline sternotomy.

\section{Material and methods}

The study is retrospective. Patients who underwent cardiac surgery at our institute via midline sternotomy in the period from 2015 to 2018 were included. Obese patients $\left(\mathrm{BMI}>30 \mathrm{~kg} / \mathrm{m}^{2}\right)$ were included in the study. Patients requiring emergency surgery, bilateral internal thoracic artery grafting, re-exploration, or with transverse fracture/s of the sternum were excluded from the study. The prophylactic use of subcutaneous wound drainage was as per the discretion of the consultant surgeon. Demographic data and diagnostic criteria for wound infection were collected from patient records and microbiology records and analysed. Ethics committee approval was waived by the department as it was a retrospective study. Written informed con- sent was taken from all the patients prior to any surgical intervention.

Out of 1079 patients who underwent cardiac surgery via midline sternotomy in the period 2015-2018, 152 patients had $\mathrm{BMI}>29 \mathrm{~kg} / \mathrm{m}^{2}$. After exclusion criteria, 128 patients were included in the study, of whom 52 were male and 76 were female. Sixty patients had prophylactic subcutaneous drainage after surgery while 68 patients were operated on without prophylactic subcutaneous drainage. Patients undergoing on-pump coronary artery bypass grafting (OnCABG), off-pump CABG (OPCABG) and valve replacement were included in the study. Those patients who received prophylactic subcutaneous drains were put in group A and those who did not receive prophylactic subcutaneous drains were put in group B.

All patients received pre-incision intravenous antibiotics. The surgical site was scrubbed with $5 \%$ povidone iodine and covered with antimicrobial incise drape (Ioban 3M).

The skin was routinely incised with a scalpel and subcutaneous fat dissected by electrocautery, avoiding skin edges. The wound was irrigated with $50 \mathrm{ml}$ of saline and $5 \%$ povidone iodine solution just before skin closure. The ectus sheath was approximated with continuous 0-monofilament polyamide and the pectoralis major approximated with 2-0 polyglycolic multifilament continuous and subcutaneous tissue with 2-0 polyglycolic acid continuous in 2-3 layers depending on the thickness of subcutaneous tissue, leaving no dead space. The skin was closed by 2-0 monofilament polyamide interrupted horizontal mattress fashion. There were no differences in the surgical procedures between the latter a prior period, except that a multipore suction drain tube (romovac suction drain no 14/16) was inserted along the entire length of the subcutaneous tissue. The exit of the drain was separated from the incisions and was connected to a charged suction chamber. The suction drain was removed once it was serosanguinous/ serous in nature with quantity less than $30 \mathrm{ml} /$ day. All diabetic patients were investigated for glycated haemoglobin $\left(\mathrm{HbA}_{1 \mathrm{c}}\right)$ level. In elective and emergency procedures, blood sugar levels were kept below $180 \mathrm{mg} / \mathrm{dl}$ in the perioperative period by short and long acting insulin and continued 2 weeks into the post-operative period or until the infection resolved. As per the institute policy, patients received preoperative intravenous antibiotics: piperacillin-tazobactam with amikacin and continued until post-operative day 5 and the incision site was monitored daily after the $3^{\text {rd }}$ day. In case of suspected SSI, wound cultures were sampled and antibiotic given as per the culture report. Also a few sutures were removed to drain collected hematoma or seropurulent fluid. Localised slough was debrided with secondary suturing. Wounds with extensive slough were debrided serially with vacuum assisted closure (VAC) dressing until followed by secondary suturing. For all patients with wound infection suspected of sternal dehiscence, chest skiagrams were done to look for bone disruption or wire abnormalities. Apart from that, all patients with wound discharge, fever, or chest pain were checked for any sternal instability. 
Table I. Demographic data

\begin{tabular}{lcccc} 
Parameter & $\begin{array}{c}\text { With } \\
\text { drain }\end{array}$ & $\begin{array}{c}\text { Without } \\
\text { drain }\end{array}$ & Total & P-value \\
No. of patients & 60 & 68 & 128 & \\
\hline Male & 24 & 28 & 52 & \\
\hline Female & 36 & 40 & 76 & \\
\hline $\begin{array}{l}\text { Age (mean } \pm \text { SD) } \\
\text { [years] }\end{array}$ & $67.3 \pm 4.6$ & $69 \pm 5.6$ & & 0.11 (NS) \\
\hline Diabetes mellitus & 48 & 62 & 110 & NS \\
\hline $\begin{array}{l}\text { Smoker/tobacco } \\
\text { addict }\end{array}$ & 26 & 28 & 54 & NS \\
\hline CRF & 8 & 16 & 24 & NS \\
\hline PVD & 4 & 6 & 10 & ND \\
\hline BMI (mean \pm SD) & $31.1 \pm 1.2$ & $30.8 \pm 1.5$ & & 0.48 (NS) \\
\hline COPD/asthma & 13 & 18 & 31 & 0.23 (NS) \\
\hline Valve replacement & 9 & 8 & 17 & NS \\
\hline OnCABG & 6 & 4 & 10 & NS \\
\hline OPCAB & 45 & 56 & 101 & NS \\
\hline
\end{tabular}

CRF - chronic renal failure, PVD - peripheral vascular disease, COPD - chronic obstructive pulmonary disease, OnCABG - on-pump coronary artery bypass grafting, OPCAB - off-pump coronary artery bypass grafting.

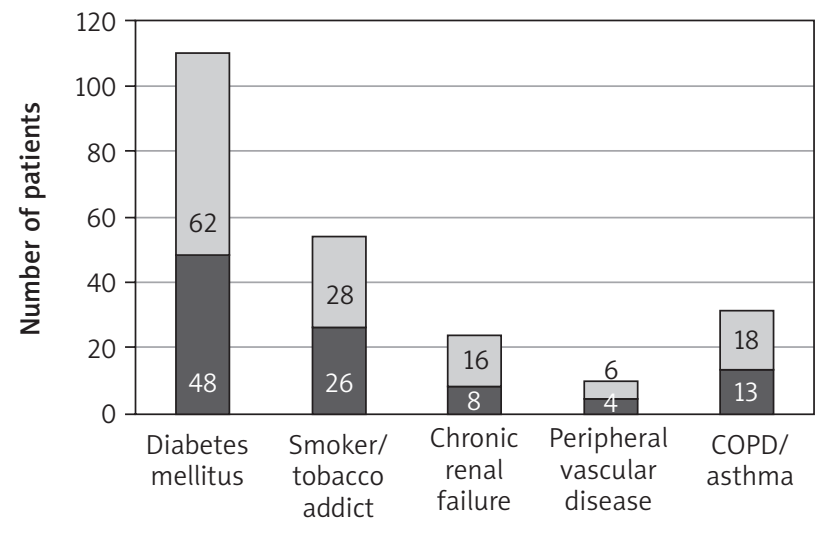

Comorbidities

$\square$ With drain $\square$ Without drain

Figure 1. Co-morbidity wise distribution of patients with and without drain

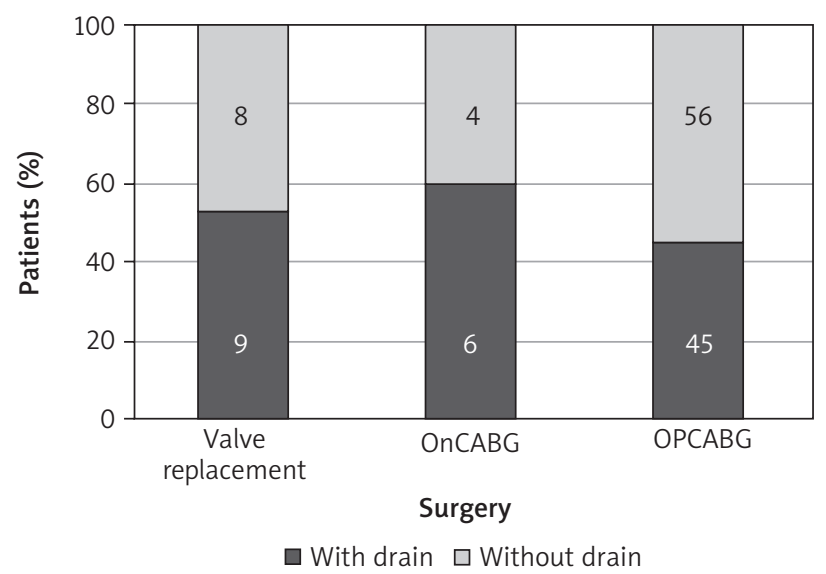

Figure 2. Type of surgery- wise distribution of patients
Patients with sternal dehiscence with mediastinitis were taken for formal exploration, washing, sternal rewiring and closure over mediastinal and subcutaneous drainage

SSI cases were diagnosed within 30 postoperative days (POD) according to Centers for Disease Control and Prevention (CDC) criteria:

- Purulent drainage with or without laboratory confirmation from the superficial incision.

- Organisms isolated from an aseptically obtained culture of fluid or tissue from the superficial incision.

- At least one of the following signs or symptoms of infection: pain or tenderness, localized swelling, redness, or heat and superficial incision were deliberately opened by surgeon, unless the incision was culture-negative, and diagnosed by a surgeon.

We used the Society of Thoracic Surgeons (STS) definition for deep sternal wound infection (DSWI) - infection involving any or all of the muscle, bone or mediastinum that occurred within 30 days of the operation, required operative intervention such as incision and drainage, debridement or re-exploration with primary or delayed closure, VAC dressing or had positive wound cultures and the patient was not receiving antibiotics at the time of sampling and received antibiotic treatment beyond routine postoperative prophylaxis (day 5) [6, 7].

Primary parameters analysed include number of patients requiring treatment for superficial SSI in terms of oral antibiotics beyond routine and/or daily dressing of the wound and healing by secondary intention and for DSWI debridement with secondary suturing and/or prolonged IV antibiotic course beyond routine with/without VAC therapy, re-exploration and re-wiring for frank mediastinitis. Secondary parameters include hospital stay and the need for readmission for deep surgical site infection within 30 days.

\section{Statistical analysis}

All categorical variables were analysed with the $\chi^{2}$ test with two-tailed $p$-value and Fisher's exact $t$ test. Continuous variables were analysed with the unpaired $t$ test. SPSS 16 software was used for statistical calculations. A $p$-value less than 0.05 was considered to be significant.

\section{Results}

One hundred and twenty-eight patients were included in the study, with 60 forming the case cohort, and data were compared with the control cohort of 68 patients who did not receive prophylactic subcutaneous wound drainage. 52 were male and 76 female patients. Mean age was 67 and 69 years respectively. The incidence of diabetes mellitus, peripheral vascular disease, chronic renal failure and chronic obstructive pulmonary disease (COPD) did not differ significantly between the two groups. Mean BMI was 31.1 and $30.8 \mathrm{~kg} / \mathrm{m}^{2}$ (Table I, Figures 1 and 2).

Twenty-seven patients of $128(21 \%)$ included in the study developed SSI. 3 out of $60(5 \%)$ patients in the wound drainage group (group A) developed superficial SSI as against 9 out of 68 (13\%) patients who did not receive 
Table II. Statistical analysis

\begin{tabular}{|c|c|c|c|c|}
\hline Variable & A - with drain (60) & B - without drain (68) & Total & $P$-value \\
\hline $\begin{array}{l}\text { Superficial SSI } \\
\text { Prolonged oral antibiotics and/or healing by } \\
\text { secondary intention with daily C\&D }\end{array}$ & 3 & 9 & $12(9.3 \%)$ & NS \\
\hline DSWI: & 3 & 12 & 15 (11.7\%) & 0.03 (sig.) \\
\hline $\begin{array}{l}\text { - Debridement with secondary suturing and/or } \\
\text { - Prolonged iv antibiotics for SSI or }\end{array}$ & 2 & 7 & 9 & NS \\
\hline$\%$ Need for VAC dressing & 1 & 5 & 6 & NS \\
\hline Re-exploration with rewiring & 0 & 2 & 2 & NS \\
\hline Hospital stay [days] & $8.3 \pm 2.9$ & $9.7 \pm 3.5$ & & 0.04 (sig.) \\
\hline $\begin{array}{l}\text { Need for re-admission within } 30 \text { days due to } \\
\text { wound dehiscence }\end{array}$ & 1 & 2 & & NS \\
\hline
\end{tabular}

Table III. Univariate analysis of risk factors for SSI

\begin{tabular}{|c|c|c|c|c|}
\hline \multirow[t]{2}{*}{ Risk factors } & \multicolumn{2}{|c|}{ Incidence of SSI } & \multirow[t]{2}{*}{$P$-value } & \multirow[t]{2}{*}{ OR $(95 \% \mathrm{Cl})$} \\
\hline & $\begin{array}{l}\text { Infection } \\
(n=12)\end{array}$ & $\begin{array}{l}\text { No infection } \\
(n=116)\end{array}$ & & \\
\hline \multicolumn{5}{|l|}{ Gender: } \\
\hline Male & $5(41.7 \%)$ & 47 (40.5\%) & \multirow[t]{2}{*}{0.938 (NS) } & \multirow[t]{2}{*}{$1.0(0.3-3.5)$} \\
\hline Female & $7(58.3 \%)$ & 69 (59.5\%) & & \\
\hline $\mathrm{DM}$ & $12(100.0 \%)$ & 98 (84.5\%) & 0.141 (NS) & - \\
\hline Smoking & $9(75.0 \%)$ & 45 (38.8\%) & $0.016(\mathrm{~S})^{*}$ & $4.7(1.2-18.4)^{*}$ \\
\hline CRF & $8(66.7 \%)$ & $16(13.8 \%)$ & $<0.001(\mathrm{~S})^{*}$ & $12.5(3.4-46.3)^{\star}$ \\
\hline PVD & $2(16.7 \%)$ & $4(3.4 \%)$ & $0.039(\mathrm{~S})^{*}$ & $5.6(0.9-34.4)^{*}$ \\
\hline COPD & $8(66.7 \%)$ & $23(19.8 \%)$ & $<0.001(\mathrm{~S})^{*}$ & $8.1(2.2-29.2)^{*}$ \\
\hline Drain & $3(25.0 \%)$ & $57(49.1 \%)$ & 0.111 (NS) & $0.3(0.1-1.3)$ \\
\hline \multicolumn{5}{|l|}{ Surgery: } \\
\hline Valve & $3(25.0 \%)$ & $14(12.1 \%)$ & \multirow[t]{3}{*}{0.444 (NS) } & \multirow[t]{3}{*}{-} \\
\hline OnCAB & $1(8.3 \%)$ & $9(7.8 \%)$ & & \\
\hline OPCAB & $8(66.7 \%)$ & 93 (80.2\%) & & \\
\hline
\end{tabular}

${ }^{*} \chi^{2}$ test; $p<0.05-$ significant.

prophylactic subcutaneous wound drainage (group B), though the numbers did not reach statistical significance. All of these patients received only a longer duration of oral antibiotics beyond a normal of 7 days with daily dressing allowing the wound to heal by secondary intention (Table II).

Three out of 60 patients (5\%) patients in group A developed DSWI as against 12 of 68 (17\%) patients in group B, which was significantly higher. In group A, 3 patients required debridement with secondary suturing and a prolonged IV antibiotic course while 1 patient required serial debridement followed by VAC dressing for a period of 5 days and secondary suturing with IV antibiotics for a period of 14 days. He was discharged on post-operative day 18.

In group B, 7 patients with DSWI required debridement with secondary suturing while 5 patients required serial debridement with VAC dressing followed by secondary suturing with IV antibiotics and were discharged 13-19 days postoperatively. In addition, 2 patients required formal reexploration on POD-7 and POD-9 for frank mediastinitis with sternal dehiscence and re-wiring. While one patient was discharged on day 21, another patient succumbed on day 16 due to persistent septicaemia and multi-organ dysfunction.

The incidence of DSWI was significantly higher in group $B$ as compared to group A patients. The requirement for VAC dressing or debridement with secondary suturing was higher in group B patients than group A, but it was not found to be statistically significant.

Mean hospital stay for group A patients (8.3 days) was found to be less than group B patients (9.7 days) and was found to be statistically significant. There were 2 re-admissions in group $B$ as compared to 1 admission in group A patients. The re-admitted patients had DSWI and required debridement with secondary suturing and IV antibiotics.

From the univariate analysis, it appears that surgical site infection (SSI) was influenced by the factors mainly tobacco smoking/chewing, chronic renal failure (CRF), peripheral vascular disease (PVD) and COPD (Table III). 
Table IV. Multivariate analysis of risk factors for SSI

\begin{tabular}{lccc} 
Risk factors & OR & $95 \% \mathrm{Cl}$ & P-value \\
Gender $(\mathrm{M} / \mathrm{F})$ & 4.4 & $0.5-42.1$ & $0.196(\mathrm{NS})$ \\
\hline $\mathrm{DM}(\mathrm{Y} / \mathrm{N})$ & - & - & - \\
\hline Tobacco smoker/chewer $(\mathrm{Y} / \mathrm{N})$ & 2.8 & $0.1-71.1$ & $0.526(\mathrm{NS})$ \\
\hline CRF $(\mathrm{Y} / \mathrm{N})$ & 0.1 & $0.0-1.4$ & $0.095(\mathrm{NS})$ \\
\hline PVD $(\mathrm{Y} / \mathrm{N})$ & 5.7 & $0.1-260.5$ & $0.371(\mathrm{NS})$ \\
\hline COPD $(\mathrm{Y} / \mathrm{N})$ & 0.1 & $0.0-1.5$ & $0.090(\mathrm{NS})$ \\
\hline Drain $(\mathrm{Y} / \mathrm{N})$ & 2.7 & $0.5-13.5$ & $0.227(\mathrm{NS})$ \\
\hline Surgery - VALVE & 1 & - & - \\
\hline Surgery - OnCAB & 0.3 & $0.0-5.9$ & $0.427(\mathrm{NS})$ \\
\hline Surgery - OPCAB & 3.3 & $0.2-63.3$ & $0.433(\mathrm{NS})$ \\
\hline
\end{tabular}

Table V. Univariate analysis of risk factors for DSWI

\begin{tabular}{|c|c|c|c|c|}
\hline \multirow{2}{*}{$\begin{array}{l}\text { Risk } \\
\text { factors }\end{array}$} & \multicolumn{2}{|c|}{ Incidence of DSWI } & \multirow[t]{2}{*}{$P$-value } & \multirow[t]{2}{*}{ OR $(95 \% \mathrm{Cl})$} \\
\hline & $\begin{array}{l}\text { Infection } \\
(n=15)\end{array}$ & $\begin{array}{l}\text { No infection } \\
\quad(n=113)\end{array}$ & & \\
\hline \multicolumn{5}{|l|}{ Gender: } \\
\hline Male & 3 (20.0\%) & 49 (43.4\%) & \multirow[t]{2}{*}{0.083 (NS) } & \multirow[t]{2}{*}{$0.3(0.1-1.2)$} \\
\hline Female & $12(80.0 \%)$ & 64 (56.6\%) & & \\
\hline $\mathrm{DM}$ & $15(100.0 \%)$ & 95 (84.1\%) & 0.095 (NS) & - \\
\hline Smoking & $12(80.0 \%)$ & $42(37.2 \%)$ & $0.002(\mathrm{~S})^{*}$ & $6.7(1.8-25.3)$ \\
\hline CRF & $9(6.7 \%)$ & $15(4.4 \%)$ & $<0.001(\mathrm{~S})^{*}$ & $9.8(3.1-31.5)$ \\
\hline PVD & $1(16.7 \%)$ & $5(83.3 \%)$ & 0.700 (NS) & $1.5(0.2-14.2)$ \\
\hline COPD & $6(40.0 \%)$ & 25 (22.1\%) & 0.129 (NS) & $2.3(0.8-7.2)$ \\
\hline Drain & $3(20.0 \%)$ & 57 (50.4\%) & $0.026(\mathrm{~S})^{*}$ & $0.2(0.1-0.9)$ \\
\hline \multicolumn{5}{|l|}{ Surgery: } \\
\hline Valve & $1(6.7 \%)$ & $16(14.2 \%)$ & \multirow[t]{3}{*}{0.145 (NS) } & \multirow[t]{3}{*}{-} \\
\hline OnCAB & $3(20.0 \%)$ & $7(6.2 \%)$ & & \\
\hline OPCAB & 11 (73.3\%) & 90 (79.6\%) & & \\
\hline
\end{tabular}

${ }^{*} \chi^{2} ; p<0.05-$ significant.

Table VI. Multivariate analysis of risk factors for DSWI

\begin{tabular}{lccc} 
Risk factors & OR & $95 \% \mathrm{Cl}$ & P-value \\
Gender $(\mathrm{M} / \mathrm{F})$ & 0.1 & $0.0-0.5$ & $\mathbf{0 . 0 1 1}(\mathrm{S})$ \\
\hline $\mathrm{DM}(\mathrm{Y} / \mathrm{N})$ & 0.000 & - & - \\
\hline Smoker $(\mathrm{Y} / \mathrm{N})$ & 17.9 & $2.1-154.1$ & $0.009(\mathrm{~S})$ \\
\hline $\mathrm{CRF}(\mathrm{Y} / \mathrm{N})$ & 2.5 & $0.3-18.7$ & 0.383 \\
\hline $\mathrm{PVD}(\mathrm{Y} / \mathrm{N})$ & 0.4 & $0.0-67.2$ & 0.760 \\
\hline COPD $(\mathrm{Y} / \mathrm{N})$ & 1.2 & $0.1-13.3$ & 0.910 \\
\hline Drain $(\mathrm{Y} / \mathrm{N})$ & 0.2 & $0.0-1.3$ & 0.091 \\
\hline Surgery - VALVE & 1 & - & - \\
\hline Surgery - OnCAB & 0.1 & $0.0-9.6$ & 0.282 \\
\hline Surgery - OPCAB & 0.3 & $0.0-52.1$ & 0.660 \\
\hline
\end{tabular}

To determine which are the factors influencing SSI when considered together, logistic regression analysis was done.

All the variables were entered at the same time using the ENTER method in SPSS 16 software. The omnibus test for model coefficients was statistically significant ( $p$-value $<0.01$ ), indicating that our model with predictors fit the data as compared to no predictors. We used the HosmerLemeshow goodness of fit test to check whether there is a difference between observed and predicted outcomes. The Hosmer-Lemeshow test revealed no statistically significant $(p=0.889)$ difference, indicating that the model fit. Nagelkerke R square was 0.36 , indicating that $36 \%$ of variation can be explained by significant factors influencing it (predictors and outcome). Statistical significance was considered at $p<0.05$.

Among all factors, none was found to be significant $(p<0.05)$ in multivariate analysis (Table IV).

From the univariate analysis, it appeared that DSWI was influenced mainly by the factors tobacco smoking/chewing, CRF and drain. To determine which are the factors influencing DSWI when considered together, logistic regression analysis was done (Table V).

All the variables were entered at the same time using the ENTER method in SPSS 16 software. The omnibus test for model coefficients was statistically significant $(p<0.001)$, indicating that our model with predictors fit the data as compared to no predictors. We used the HosmerLemeshow goodness of fit test to check whether there is a difference between observed and predicted outcomes. The Hosmer-Lemeshow test revealed no statistically significant ( $p=0.975)$ difference, indicating that the model fit. Nagelkerke $R^{2}$ was 0.49 , indicating that $49 \%$ of variation can be explained by significant factors influencing it. Statistical significance was considered at $p<0.05$.

Among all factors, gender and tobacco smoking/chewing were found to be significant ( $p$-value $<0.05)$ in multivariate analysis (Table VI).

\section{Discussion}

SSI is considered to be one of the most serious infectious complications of surgery. There are studies - randomised, non-randomised and meta-analysis - showing numerous modifiable and nonmodifiable causative factors for post-operative surgical site infection after midline sternotomy in open-heart surgery. Patient factors such as nutritional status, hygiene, and strict control of blood sugar levels have been stressed. Operative risk factors include avoiding use of bone wax, excessive electrocautery, prolonged surgical time, tight and optimal sternal wiring and wound closure, etc. [8].

Obesity is considered as one of the important predictors of post-sternotomy wound complications. A few studies have indicated increased risk of SSI in obese patients to $7-23 \%$ [9]. The following mechanisms have been attributed to increased susceptibility to wound infections in obese patients after sternotomy - increased wound tension, bulky subcutaneous tissue that makes identification of the midline difficult and faulty sternal splitting, poorly vascularised adipose tissue with less resistance to infection and a substrate for bacteria. Antibiotic prophylaxis is generally not adjusted for the increased weight, resulting in insuffi- 
cient drug levels. Obese patients have a higher incidence of diabetes, and therefore impaired wound healing. Obesity is also associated with postoperative respiratory problems, which may require longer ventilation time. This fact and the difficult expectoration may lead to sternal dehiscence [10].

Depth of subcutaneous fat has been shown to be a strong risk factor for SSI and has been shown to be a useful predictor for SSI risk [11].

It is also believed that superficial SSI predisposes to DSWI.

The incidence of s-SSI is related to multiple factors which also include the amount of bacteria in the wound, formation of hematoma, pool of effusion, potential subcutaneous dead space, disturbance of the local circulation, and the amount of bacteria in the surgical organ. It has been postulated that the presence of hematoma, serous fluid, and dead space in surgical incision wounds acts as a culture medium and thus increases the risk of infection. It is imperative to remove the blood and serous fluids from the wound by drains before they get infected. The drains often have a tendency to get luminal obstruction ranging from a few hours to 2 days [9]. Hence, it is recommended that such drains be connected to a powerful suction. This concept is frequently implemented in plastic surgery.

A few studies from non-cardiothoracic surgical departments have used a prophylactic subcutaneous wound drain to decrease the incidence of SSI and obtained mixed results. A meta-analysis showed that prophylactic subcutaneous drainage to prevent wound complications is not efficient in gynaecology, cholecystectomies, and inguinal hernia repairs, while it is commonly used after abdominoperineal excision of the rectum and repair of incisional hernia [11, 12].

Above data show that the use of postoperative subcutaneous wound drainage is not universally accepted. In addition, drains may not be efficacious and cause discomfort, bad cosmesis and increased hospital stay on their own.

We have used prophylactic subcutaneous suction wound drains selectively in obese patients. We noted an incidence of $21 \% \mathrm{SSI}$ in post-sternotomy wounds in obese patients undergoing cardiac surgery, which was similar to the previously noted incidence of $7-23 \%$ of cases [9]. The incidence of superficial SSI was $9.3 \%$ and DSWI $11.7 \%$. The number of patients with superficial SSI requiring prolonged oral antibiotics with wound healing by secondary intention did not significantly differ in those with (5\%) and those without (13\%) prophylactic subcutaneous wound drainage, though the numbers were higher in the no suction group, while deep SSI was noted to be significantly more frequent in those without prophylactic subcutaneous wound drainage $(17 \%)$ as against $5 \%$ of patients with subcutaneous drains having deep SSI. More patients required VAC dressing and re-exploration with re-wiring for mediastinitis, but the numbers were not statistically significant. We noted a statistically significant increase in number of days of hospitalisation in obese patients who did not receive a pro- phylactic subcutaneous wound drain. The univariate and multivariate analysis did not show any significant impact of using prophylactic subcutaneous wound drainage on superficial SSI. A subcutaneous wound drain significantly reduced DSWI in univariate analysis, but it did not show statistically significant reduction in DSWI in multivariate analysis. In our study, we found that tobacco chewer/smokers and female patients were at significantly higher risk of developing DSWI after sternotomy.

It is an observational, retrospective study. The study does not account for various surgeons involved in closure, though the technique followed in the institute is the same among all the surgeons.

The sample size is small. A larger sample size of the patient population would give better insights into the efficacy of using subcutaneous drains prophylactically in obese patients. Other confounding variables known to affect wound healing such as pre-operative nutritional status, prolonged pre-operative hospital admission, etc, are not considered.

\section{Disclosure}

The authors report no conflict of interest.

\section{References}

1. Loop FD, Lytle BW, Cosgrove DM, Mahfood S, McHenry MC, Goormastic M, Stewart RW, Golding LA, Taylor PC. J. Maxwell Cham-berlain Memorial Paper. Sternal wound complications afterisolated coronary artery bypass grafting: early and latemortality, morbidity, and cost of care. Ann Thorac Surg 1990; 49: 179-186.

2. Cardosi RJ, Drake J, Holmes S, Tebes SJ, Hoffman MS, Fiorica JV, Roberts WS, Grendys Jr EC. Subcutaneous management of vertical incisions with 3 or more centimetres of subcutaneous fat. Am J Obstet Gynecol 2006; 195: 607-614.

3. Shaffer D, Benotti PN, Bothe Jr A, Jenkins RL, Blackburn GL. A prospective, randomized trial of abdominal wound drainage in gastric bypass surgery. Ann Surg 1987; 206: 134-137.

4. Morykwas MJ, Simpson J, Punger K, Argenta A, Kremers L, Argenta J. Vacuumassisted closure: state of basic research and physiologic foundation. Plast Reconstr Surg 2006; 117 (7 Suppl): 121S-126S.

5. Baier PK, Gluck NC, Baumgartner U, Adam U, Fischer A, Hopt UT. Subcutaneous Redon drains do not reduce the incidence of surgical site infections after laparotomy. A randomized controlled trial on 200 patients. Int J Colorectal Dis 2010; 25: 639-643.

6. Shahian DM, Jacobs JP, Edwards FH, Brennan JM, Dokholyan RS, Prager RL, Wright CD, Peterson ED, McDonald DE, Grover FL. The Society of Thoracic Surgeons National Database. Heart 2013; 99: 1494-1501.

7. The Society of Thoracic Surgeons. STS Adult Cardiac Surgery Database data collection forms and specifications. Version 2.73.

8. Lazar HL, Salm TV, Engelman R, Orgill D, Gordon S. Prevention and management of sternal wound infections. J Thorac Cardiovasc Surg 2016; 152: 962 972.

9. Gupta P, Kumar R. Role of subcutaneous suction drain in reducing surgical site infections after emergency laparotomy. Int Surg J 2017; 4: 2717-2720.

10. Lamm P, Godje OL, Lange T, Reichart B. Reduction of wound healing problems after median sternotomy by use of retention sutures. Ann Thorac Surg 1998; 66: 2125-2126.

11. Manzoor B, Heywood N, Sharma A. Review of subcutaneous wound drainage in reducing surgical site infections after laparotomy. Surg Res Pract 2015; 2015: 715803.

12. van Walraven C, Musselman R. The Surgical Site Infection Risk Score (SSIRS): a model to predict the risk of surgical site infections. PLoS One 2013; 8 e67167. 